\title{
The Reception of Olivia Manning's The Great Fortune in Romania
}

\author{
Cristina Zimbroianu ${ }^{1}$ \\ ${ }^{1}$ Department of English Philology, Autonomous University of Madrid, Madrid, Spain \& Department of \\ English Philology, Applied Linguistics to Science and Technology, Technical University of Madrid \\ E-mails: cristina.zimbroianu@uam.es \& cristina.zimbroianu@upm.es
}

\begin{abstract}
Manning's (1908-1980) novel The Great Fortune (1960) is the first Second World War novel of a six-part novel series titled Fortunes of War. Set in Bucharest, Romania, the novel portrays the historical events of the first year of the war (1939-1940) and how these affect Romanian society and the English community. The novel was well-received in England, and in 1987 was adapted to a television serial issued by BBC. In Romania, the response of the critics after the communist regime was rather harsh, accusing Manning of misinterpreting Romanian reality. Moreover, considering that Manning portrays not only the wealth of high society but also the misery and the political conflicts of those times with the fascist Guard in the background, it could be stated that in 1960 when the novel was reviewed by the censorship board, it might not have been positively evaluated. Therefore, this article analyses the reception of The Great Fortune in Romania during and after the Communist regime from a historical perspective focusing on critics and censors' responses to determine whether censorship influenced the reception of the novel in Romania. To undertake this study the censorship files located at the National Archives in Bucharest, as well as articles guarded in various libraries in Romania, were consulted.
\end{abstract}

Keywords: Manning, Second World War, Romania, Bucharest, censorship, criticism, history, reception studies

Olivia Manning (1908-1980) was an English writer of World War II who shared the wartime setting with other novelists such as Phyllis Bottom (1984-1963), both of whom wrote their works in English. Manning is known for a series of six novels written after the Second World War. These were later published as two trilogies, The Balkan Trilogy (1981) - The Great Fortune (1960), The Spoilt City (1962) and Friends and Heroes (1965) - and The Levant Trilogy (1982) - The Danger Tree (1977), The Battle Lost and Won (1978), and The Sum of Things (1980), all of them based on her war adventures. The Great Fortune opens the first trilogy and relates the experiences of the couple Harriet and Guy Pringle who travel to Bucharest, Romania where Guy must occupy a lecturer position at the University of Bucharest. The novel follows the historical events of 1939-1940, and how these affect the Romanian society and the English community in Bucharest. Manning describes historical incidences like the assassination of the Romanian prime minister, Armand Călinescu, by the Iron Guard, the fascist movement in Romania, the fall of Poland, the invasion of Denmark and Norway by Germany, the coup that replaces Gheorghe Argeșanu who exercised as prime minister for a short period, with Constantin Argetoianu, and the entrance of Italy into the war on the side of Germany.

It should be mentioned that The Great Fortune is a novel based on Manning's experiences in Romania, which was translated into Romanian seven years after the fall of the communist regime, in 1996 into Marea Șansă by Diana Stanciu. Manning stated that she did not have "a capacious imagination nor a feel for fantasy" and she insisted that she wrote entirely "out of experience" (Deirdre 2012, 24). The Great Fortune portrays some of Manning's experiences that would be controversial to Romanian readers, censors, and critics. Thus, Harriet and Guy Pringle represent Olivia Manning and her husband Reggie Smith. The newly married couple travels by train to Bucharest in 1939, where Guy is expected to teach English literature at the University of Bucharest. Guy had already spent a year there; so Romania was not unknown to him. Harriet, a young woman of twentyfour, discovers that Guy had a special relationship with one of his students, Sofia, and she must learn to cope with Sofia's presence as well as Guy's absence, as he is always absorbed in his work at the university or visiting his countless friends, 
being such a sociable and extroverted character. In Bucharest, Harriet admires the architecture of the city, its parks, restaurants and foods, but she also meets the beggars, the poor peasants, and witnesses the protests of the Fascist Iron Guard, the murder of the prime minister Armand Călinescu, and the instability of Romania finally occupied by the Soviets.

English and American critics issued a series of positive reviews and monographs on Manning's war novels, such as British Women Fiction Writers 1900-1960. Volume two (1998) edited by Harold Bloom which encloses a series of reviews of Manning's work by writers including Anthony Burgess, Hollis Alpert, and Peter Straub. Manning's trilogies became famous in 1987 when BBC produced a television serial starring Kenneth Branagh as Guy and Emma Thompson as Harriet. In Romania, critics issued several reviews and articles, mainly after the communist regime, like “Olivia Manning și imaginea Bucureștiului” ("Olivia Manning and the Image of Bucharest") (1997) published by Convorbiri literare (Literary Conversations) or "O geloasă" (“A Jealous Woman") (1996) by Grete Tartler. Romanian critics debated the standpoint of Manning regarding Bucharest, but they did not focus on the reception of the novel during the communist dictatorship. Thus, this paper analyses the reception of The Great Fortune in Romania during and after the Communist regime from a contextactivated perspective within the field of reception studies as presented by Janet Staiger (1992) in Interpreting Film. Studies in the Historical Reception of American Cinema, in order to determine whether censorship had a positive or negative effect on the reception of the novel. To undertake this study, the censorship files located at The National Archives of Romania in Bucharest and critical publications about Manning produced in Romania during and after the dictatorial regime were consulted.

According to Janet Staiger, the object of research of reception studies is the history of interactions between reader and texts (8). In Interpreting Film. Studies in the Historical Reception of American Cinema, Staiger refers to "contextactivated" theories that focus on contexts for reading experiences, and historical circumstances become central (35). In Romania, the political and historical events at the time when The Great Fortune was examined by the censorship board may have influenced the positive reception by the censors, as the evaluation of the novel was based on the framework set by the communist ideology. Without a positive response from the censors, the novel could not be translated or published. One of the classical approaches of context-activated theories is that of Hans Robert Jauss. The reception theory proposed by Jauss is a response to the Marxist and Formalist schools that deprived literature of "the dimension of its reception and influence" (Jauss 18). In both literary theories, the reader plays a limited role. As Jauss suggests, Marxist aesthetics treats the reader the same as the author, enquiring about his social position and endeavouring to recognize him in the structure of a specific society (18). On the other hand, the Formalist school presupposes that the reader has the theoretical training of a philologist who can distinguish and analyse artistic devices. None of these schools recognizes the authentic role of the reader as the genuine addressee "for whom literary work is primarily destined" (19). Considering these positions regarding the role of the reader, Jauss attempts to fill the gap of these two approaches focusing on the public as an active factor being itself an element that contributes to the creation of history (19).

Jauss's prime interest is not in the response of a single reader at a given time, but in the changing, interpretative and evaluative responses over a span of time enclosed in the concept "horizon of expectation" proposed by Jauss (25). Since later regular readers and literary critics have access to the literary text and to the published responses of former readers and scholars, then an evolving historical tradition develops critical interpretations and evaluations of a given literary work. This leads to a historical tradition of reception, which focuses on social, artistic, historical, and political factors. Thus, the historical reception of Manning's novel in Romania is given by the response of the censors, who decide whether the novel should reach or not the Romanian libraries and the response of the critics who had access to the novel. Nonetheless, to understand the responses of these readers, the historical context of Romania during the communist period should be studied, more precisely the functioning of the censorship apparatus.

After introducing the theoretical framework, this paper will proceed with the presentation of various aspects, such as the context of censorship in Romania, the reaction of censors to Manning's novel and the reaction of critics. The presentation of the context of censorship is necessary to understand the censors' evaluation of the novel, which was influenced by the laws imposed by the communist regime. From the analysis conducted, it appears that the original censorship of Manning's novel in 1960 had an impact on the reception of the work after the fall of the communist regime. Romanian critics published several reviews and articles in 1992 and 1996, several years after the communist regime, in which they seemed to focus on the same aspects as the censors, i.e., the poor peasants, the presence of beggars throughout Bucharest, the condescending view of the English on Romania and the situation of the Jews. These aspects are dealt with in the section entitled "The Critics' Reception of The Great Fortune". Furthermore, the section dedicated to the reception by the censors is divided into subsections in order to give a clear picture of the aspects that the censors 
focused on, such as the representation of the Romanian people, the representation of the Jewish people, political references considered subversive, and the expectation of authenticity.

Since 1938, censorship in Romania was regulated by Decret-lege privind introducerea stării de asediu (the Decree-Law Regarding the Introduction of the Siege State). Article four of this law allowed the military authorities to "censor the press and any other printed material having the right to refrain the publishing of any newspaper or other publication, or the publishing of certain news and articles" (qtd. in Scurtu, Stănescu-Stanciu, Scurtu). Under this law, the institution that controlled censorship in 1945 was the Cenzura Centrală Militară (Central Military Censorship) aimed at supervising the Press Censorship Service, the Foreign Post Censorship Service and Interior Post Censorship Service. Therefore, Central Military Censorship was not a Soviet invention, as it functioned before the entrance of the Soviet troops in Romania (Corobca, Instituţia cenzurii 9). On January 1946, the Allied Control

Commission (CAC) was created to introduce the communist regime. This institution participated in the foundation of the main soviet-communist institutions: the party, the Securitatea (security police), and the censorship system (Corobca, Controlul cărţii 12).

The CAC oversaw the book purging and the employment of "prior censorship" to control the post as well as the publishing of any material (Corobca, Controlul cărţii 15-17). On November 7, 1947, the CAC ceased to operate. On May 20, 1949, the Ministers Council issued Decree 214, which stipulated that the Directorate of Press and Printing of the former Minister of Arts and Information was transformed into the Direcţia generală a presei şi a tipăriturilor (the General Directorate of Press and Printing, GDPP), which was to function alongside the Ministers Council. ${ }^{1}$ In 1949, Decree 218 established the basic functions of the GDPP as follows:

General Direction of Press and Printing has the following attributions:

a) Writes the Official Bulletin of the Romanian Popular Republic.

b) Authorizes the publishing of any printed material such as newspapers, magazines, programmes, posters, etc., by taking measures regarding the accomplishment of the printing legal conditions. c) Authorizes the publishing of all books in the capital city and province.

d) Authorizes the diffusion and selling of books, newspapers, and other printings, as well as the import and export of newspapers, books, and objects of art. e) Regulates the functioning conditions of libraries, book antiquarians, public libraries, newspapers deposit and books deposit.

f) Writes and transmits to the press the official news of the Ministers Council and coordinate the activity of the press and ministries, departments, and public institutions. (File 6/1951)

The GDPP carried out its activities through seven departments, including the management of the press and periodical publications, and the management of book approval (Corobca, Controlul cărţii 89). In these departments, the lectorii (readers, as the censors were called) reviewed all national and international books, newspapers, and mail to prevent the intrusion of subversive material. It is not clear what exactly was considered subversive. As Corobca mentioned, censors did not have delimited criteria or principles to follow when developing their activity (Controlul cărţii 60). However, a report issued in January 1964 reveals that they used to disapprove aspects that went against Romanian history and people, the communist party, and the political relationships with the befriended countries (File 11/1964 4-6). They seemed to focus on issues related to the party and defended the Marxist-Leninist ideology claiming that the multiple tasks of the great responsibility they had to conduct could be accomplished only through the Marxist-Leninist learning. They also paid special attention to a profound permanent knowledge of the party's norms, its internal and external policy and the documents regarding Romania and the international working movement (File 11/1964 2).

In the late 1970 s, the censorship system intended to be more tolerant. As a result, the Comitetul pentru Presă şi Tipărituri (Committee for Press and Printing, CPP), which had taken over the General Directorate for Press and Printing on 30 May 1975, was abolished by Decree 471 of December 24, 1977 (Deletant 145). However, this suppression was merely a strategy by the party to give the impression that it wanted to loosen its control over literature (145). Deletant explains that "in practice, publishing houses and newspapers were henceforth required to verify manuscripts and articles in-house and then forward them to readers, lectori, in the Consiliul Culturii şi Educatiei Socialiste (Council of Culture and Socialist Education) for the official imprimatur" (145).

\footnotetext{
${ }^{1}$ See the fund of the Committee for Press and Printing, file number 10/1949 held at the Romanian National Archives. All translations from Romanian are my own unless otherwise stated.
} 
Books that passed through the Censorship Department were either amended and approved or sent to the Secret and Documentary Book Collection Fondul Special (the Special Collection), established in 1951. The Special Collection is significant because many of the books that were destined to be burned were saved. The DGPP decided to establish a special book collection to contain the documentary and secret books that were considered dangerous. A note from the censor dated May 22, 1964 clearly states that Special Library would protect those "publications and books that are politically harmful because of their content" (File 10/1964).

The access to these books was restricted. As the note mentions, "readers' access to the special collection is restrictive, being regulated by legal provisions, and the circulation of this material out of the special library is forbidden" (File 10/1964). Therefore, only some personalities of the regime had access to these works with a special permission, but they were never allowed to take the book out of the library and were allowed to consult it only briefly and always under the supervision of the librarian (Costea, Király, Radosav 262). The books of Special Collection were returned to the public in 1990, a year after the fall of the communist regime (143). Even today, one can see the letters $D$ for documentary and $S$ for secret on the registration cards of these books. Most of the registration cards were signed with a pencil, so these letters are barely legible, but some of the books were also marked with $D$ and $S$ on the first pages with a pen, so the letters are easy to identify today.

The Special Collection was included in the most important libraries of the country, such as the library of the Romanian Academy, the Central University Library of Bucharest or the university libraries of Cluj and Iaşi. These libraries could only keep one copy of each volume, the remaining copies were destroyed (Corobca, Controlul cărţii 81 ). The criteria by which the censors distributed the books in either the documentary or the secret collection are presented in a note from 1950-1955 on the instructions for book selection in the volume Fond Secret. Fond " $S$ " Special by Costea, Király and Radosav. According to these instructions, books were divided into three libraries: forbidden, documentary, and open. Books published before 1914 were included in the open library. Books with antiMarxist, chauvinist and anti-Semitic content were kept in the documentary library. The forbidden library guarded, among others, fascist and anti-communist books, translations of Anglo-American literature from 1920-1945 and works

\footnotetext{
${ }^{2}$ See also Zimbroianu Cristina "Evelyn Waugh's Decline and Fall and Vile Bodies in Franco's Spain and Communist Romania". Philologica Canariensia 25 (2019), pp. 86-106.
}

written by or about the royal family (Costea, Király, and Radosav 260-261). ${ }^{2}$

An important aspect concerning the censorship files kept in the National Archives in Bucharest and in the fund of the Committee for Press and Printing is that innumerable files were destroyed (Stănescu). Therefore, it is extremely difficult to find a single censorship report on a particular author, in this case Olivia Manning. If such a report is found, researchers can consider themselves extremely lucky.

However, even if a censorship report cannot be located, the library of Romanian Academy has the registration cards of books registered during the communist period. These cards can reveal whether the books in question were introduced in Special Collection, because they are marked with the letters $D$ or $S$, which means that they were forbidden to the reading public until 1990

\section{The Censors' Reception of The Great Fortune}

\subsection{Representation of the Romanian People}

The novel reached the censors of the Import-Export Directorate in 1960. According to the censor, the book was an edition of 1959 published by Hope Leresche and Steele. However, this must be an error as the novel was first published in 1960, not 1959, by William Heinemann. The volume was to be delivered to the translator Alf Adania, thus the censor had to first review the book to authorize its translation by Adania (File 7/1960). The censor's report opens by mentioning that the action develops in Bucharest before the outbreak of the Second World War (File 7/1960). Guy's activity in Bucharest seems to be misinterpreted, as the censor points out that Guy is "a civil servant with dubious relationships at the British Embassy in Bucharest" (File 7/1960). This is not correct, as Guy is a university professor, but he relates more with the members of the British Council rather than with the embassy.

Regarding Harriet, the censor underlines that she critically observes everything around and reports it to the "civilised" Britain. "Civilised" is written in inverted commas, probably to emphasize the thought that Britain is more civilised and superior to Romania. Steinberg Theodore (2005) in Twentieth-Century Epic Novels states that the British in Manning's novel were aware of their superiority and their attitude towards the Romanians "can most nicely be described as condescending" (87). Their superiority, however, might have been influenced by the Balkan 
stereotype transmitted mainly through European and American literature (Andrés Oliver 80). Maria Todorova (1997) in Imagining the Balkans explains that the Balkan stereotype stands for "filth, passivity, unreliability, misogyny, propensity for intrigue, insincerity, opportunism, laziness, superstitiousness, lethargy, sluggishness, inefficiency, incompetent, bureaucracy" (114). Most of these negative connotations are identified by Harriet in Romanian people, and the censor clearly highlights this aspect when mentioning that Harriet reports to the "civilised" Britain "on the one hand the poverty and misery, and, on the other the tasteless luxury, the typical dirt of the East and people stuffed with too much food" (File 7/1960).

The censor finds positive the fact that Manning realistically reveals the poor situation of the peasants. The peasants described are "starved, frightened figures, scrawny with pellagra, wandering about in a search for work or making a half-hearted attempt to beg"; and more descriptions of the sort can be found also on page 167 (File 7/1960). On this page, Manning refers to the shaking beggars who in the middle of the winter were half-naked: "the beggars were, as ever, half-naked, their bodies shaking fiercely in the bitter air" (Manning 167). Poor peasants and beggars have always been part of Bucharest. Peasants always suffered from poverty, and their situation worsened during the great depression when their harvest failed, and the prices of agricultural goods became unaffordable. As Roland Clark (2012) explains, "peasants with small lots found themselves in a particularly precarious situation as the value of agricultural exports plummeted and the interest rates they had to pay on bank loans soared" (227). Finding themselves in such difficulties, they decided to go to the city where their situation may somehow improve. It is surprising, however, the fact that the censor found their situation positive. A possible explanation may be given by the fact that when the peasants encountered such dramatic conditions, most of them joined the fascist movement headed by the Iron Guard (Legionaries) in hope of an improvement of their situation. Countless violent street manifestations took place in major cities where peasants and factory workers fought for their rights (Clark 227). Thus, censors might have judged positive the poverty of peasants and beggars probably because their condition did not improve despite joining the fascist Iron Guard. This means that the legionaries had not a positive effect on these people. Communists condemned the fascist legionaries because they were identified "with the capitalist class, and argued that fascist regimes took away workers' rights, using Mussolini's Labour Code of 1927 as an example" (Clark 233).

\subsection{Political References Considered Subversive}

Apart from the poverty of the peasants and the beggars, the censor also identifies some unsuitable political references. The censor's remarks are not entirely correct, for they mention that Harriet "addresses the actions of reactionary circles and highlights their actions that led to the alliance with fascist Germany" (File 7/1960). This statement is confusing, as Harriet has no active role in the Romanian "reactionary circles", she is just a passive observer of the events. The censor states that Harriet describes the struggles of a small group of people composed by "the members of the embassy, the political refugees, dubious journalists she met on the hallways of hotels and restaurants and some Romanian nobles", and her political ideas are anti-fascist, pro-British, pro-French displaying "a profound spirit against Russia and its politics, as revealed on pages 86, 102, 156, 219, 223, etc." (File 7/1960). The file does not include the exact lines considered subversive on the mentioned pages, but on page 86 Professor Inchcape tells a comic story about a drunk in a café who was insulting the king Carol II:

A drunk in a café was reviling the king calling him lecher, swindler, tyrant; all the usual things, when a member of the secret police overhearing him, said: 'How dare you speak in this manner of our great and glorious Majesty, your king and mine? 'But, but' stammered the drunk, 'I was not speaking of our King. Far from it. I was speaking of another King. In fact the king of Sweden. 'Liar', roared a policeman, everyone knows that the King of Sweden is a good man.' (Manning 1981, 85-86)

It is difficult to know why the censor considers this reference to the king to be anti-Russia, since the king is not praised, but rather criticised. Possibly, the king was seen as a symbol of a past when the communists were not leading Romania, but they still had certain power as they owned Bessarabia and Bukovina ceded to them precisely by the king Carol II (Tismăneanu 158). According to the norms issued by GDPP for the Special Collection, the works that dealt with the royal family were included in the secret and documentary libraries, so such works were forbidden. However, the main subject of Manning's novel is not the royal family, so the censor could have been more flexible on this point.

\subsection{Representation of Jewish People}

The censor considered that on pages 102, 156, 219 and 233, Manning expressed "a profound aggressive spirit towards Russia and its policy" (File 7/1960). However, the reader did not mention the exact lines considered "aggressive". Probably the censor referred to Romanians' 
negative attitude towards the Jews. On page 102, in a conversation of Harriet with the sister of Emanuel Drucker, a rich Jew banker, the woman complains that the Jews are treated deceptively by the Romanians, and her husband, a clever lawyer who worked in Germany, is not allowed to work in Romania:

'In Germany my husband was a clever lawyer. He had a big office. He comes here - and he is forbidden to practise. Why? Because he is a Jew. He must work for my brother. Why do they hate us? Even the trăsură driver when angry with his horse will shout: "Go on, you Jew.” Why is it? Why is it so?' (Manning 102)

Furthermore, on page 156, Manning describes the opinion of a Romanian character, Nikko, about the detention of Emanuel Drucker thrown in "a common cell with low criminals and perverts" (Manning 156). Nikko replies that:
'This Drucker,' he said, 'is a big crook [...] Although he describes himself as pro-British, his business is with Germany - such a thing is not uncommon here - and he thinks Germany will protect him. So he refuses. He is arrested. He is jugged. Each minute a new charge is cooked for him - treason, forgery, plotting with Germany, plotting with Britain, black-market deals and so on. One would be enough. He is a Jew, so his possessions anyway are forfeit' [...] Dugdale gave a high neigh of a laugh. 'Delicious!' he cried. Clarence asked: 'You are amused by a system of government that permits wrongful arrest, wrongful seizure of property and imprisonment for life on faked charges?' (Manning 1981, 156)

These quotes show that Jews were persecuted even before Stalin's Purge-Campaign, which was carried out in Romania from 1948 to 1953 to eliminate all Jews who belonged to the Communist Party (Tismăneanu 67). As Clark (2012) mentions "Jews had lived in the territory of present-day Romania since at least the late Middle Ages, but modern anti-Semitism in Romania dates to the wave of Jewish immigration from Polish Galicia during the eighteenth century" (44). Jews were described in Romanian documents "as sly, deceitful, ugly, smelly, cowardly, and lazy" (Clark 44). The Jews posed a problem for Romanians because the small bourgeois class included more Jews than ethnic Romanians, meaning that Jews' economic importance was growing; this led to concerns about "who truly held the power in the country - the (Jewish) bankers or those (Romanians) who worked the land" (Clark 45). As consequence, an anti-Semitic movement emerged mainly among nationalist intellectuals who adopted "anti-Semitic stereotypes from popular culture and then re-introduced them through polemical texts" (Clark 46). The historian Carol
Iancu presents the situation of Romanian Jews in the twentieth century as follows:

Professing a systematic state anti-Semitism, liberal and conservative governments ... forbade Jews from entering the judiciary, education or the state administration. Excluding Jews from public functions and from numerous economic activities, they still required them to perform military service though they would not allow them to become officers. Their children were accepted in schools with difficulty, and then only in return for higher fees. (qtd. in Clark 53)

\subsection{Expectation of Authenticity}

The last pages that are considered subversive, 219 and 223, show some characteristics of the Romanians like greediness and snobbism. On the one hand, on page 219, Yakimov complains to Guy that he was forcibly evicted by his landlady because he could no longer pay the rent and owed her more unpaid rent:

'Difficult times,' he said. 'Your poor old Yaki's homeless. Been turned out. Thrown out, in fact. Literally thrown out by m'landlady. A terrible woman. Terrible. And she's kept all m'belongings.' 'She can't do that.' Guy was indignant, but on reflection added: 'Unless, of course, you owe her some rent.' 'Only a few lei. But that wasn't the main trouble, dear boy. It was a ham-bone I found lying about. Feeling a bit peckish, I picked it up - and she caught me with the bone in m'hand. You know what's on a ham-bone, dear boy! Scarcely a mouthful, but she went mad. Mad. She hit me, kicked me, beat me over the head, screamed like a maniac: then she opened the front door and shoved me out.' [...] 'Never knew anything like it, dear boy.' (Manning 219).

It is possible that the violent attitude of the landlady was seen by the reader as censurable because it displayed a certain violence, even though this could have been the reaction of any other landlady in any other country who did not receive the rent they were owed. However, the main aspect that the censor might find problematic is probably Yakimov's hunger, which involves the fact that food was lacking. He was caught by the landlady with a "ham bone" in his hand because he had nothing to eat, and the landlady refused to share the food with him. The censor could have interpreted that the country was starving because no food was provided; such interpretations should not be made by potential readers.

On the other hand, Guy mentions on page 223, in a conversation with Harriet about the play he plans to stage 
about "Troilus and Cressida", that Romanians respond only to "snob appeal" (Manning, 223). Guy's intention is to perform the play at the National Theatre, and he needs lots of actors and costumes. Harriet is afraid that he must invest a lot of money in producing it, and she tries to persuade him to give up or do a simple reading in the lecture hall. To this Guy reacts: "'Oh no. We must do the thing in style. Rumanians only respond to snob appeal."” (223).

Guy's reference to Romanian snobbery could also be a threat to communist values. According to Merriam Webster dictionary, a snob is "one who blatantly imitates, fawningly admires, or vulgarly seeks association with those regarded as social superiors". Romanians, then, must not call for striving for social superiority, for that would mean turning to capitalism. The communist ideal was to build an equal society without social classes (Tismăneanu 13). Communism wanted to suppress private property at all costs and establish a universe of total equality (9).

The censor ends the file by stating that The Great Fortune cannot be translated and must be included in the Special Fund, more precisely in the Secret Library (File 7/1960). The novel was thus banned, and readers could not access it until 1990, a year after the fall of the regime, when the books of Special Collection became available. The censors' decision is not surprising, given the novel's content. Their task was to preserve and defend communist values and not to allow interpretations if the text was not clear enough. As the writer and translator Ştefan Augustin Doinaş mentions in the volume Censorship in Romania edited by professor Lidia Vianu, "the censor sought a language which would communicate only one thing at a time, the same thing, in fact, over and over again, and even with determination, if possible. Plurisemantic language was changed into an obvious one, which was meant to obey and serve as propaganda" (qtd. in Vianu 30).

\section{The Critics' Reception of The Great Fortune}

The negative reaction of the censors to Manning's novel in some ways anticipates the reaction of the Romanian critics who published reviews, prefaces, and articles on The Great Fortune after the communist period. In the biography of Olivia Manning, a Woman at War by Deirdre David, the historian Roy Foster mentions that Manning's war trilogies are "the best evocation of the Second World War in English" (qtd. in Deirdre 339). However, despite the critical praise of the trilogies, Foster sadly concludes that Manning's work "remains critically undervalued" (qtd. in Deirdre 400). It could be said that not only in England Manning's oeuvre is undervalued, but also in Romania. In the article entitled "Cărți despre România aparute in Occident înainte de
1989. Olivia Manning: 'The Balkan Trilogy"” (“Books about Romania published in the West before 1989. Olivia

Manning: 'The Balkan Trilogy"') published in the journal Steaua in 1992, the writer, researcher, essayist, and editor Andronescu Șerban evaluates Manning's novel from a rather negative perspective focusing mainly on Manning's description of the poor conditions in which most Romanians lived, as well as their lack of morals and values.

From the beginning Andronescu mentions that the impression Manning has of Bucharest is detestable, which is especially evident in the third volume of the Balkan Trilogy, Friends and Heroes, where Greek society is portrayed in a positive light in contrast to Romanian society (26).

Andronescu emphasises that the trilogies became bestsellers, bringing Manning a considerable income, and their task is to influence the reader's thinking. Therefore, the Romanian reader must be particularly attentive and should rather focus on the sources of the author's inspiration instead of the writer's talent (26). When Harriet Pringle /Olivia Manning travelled by train from Venice and Belgrade to Bucharest, she made a negative first impression of Romania. Arriving in Bucharest, she was annoyed by the melody of the Romanian hora, a traditional tune that has its own dance style and is nowadays mainly played at weddings. She was impressed by the begging, which was then - and still is today - a very well organised profession:

These were professional beggars, blinded or maimed by beggar parents in infancy [...] All the beggars set upon the Pringles together. One hid half a loaf behind his back to join in the age-old cry of: 'Mi-e foame, foame, foame.' They were hemmed in by a stench of sweat, garlic and putrid wounds. (Manning 22)

Andronescu claims that Manning is comparing the Romanians to the Nazis. It seems that the people of Bucharest did not walk properly on the sidewalks of the city and did not let anyone pass, "not even she, the

Englishwoman," using this phrase to pejoratively imply that she was a superior citizen. She compares this attitude of the Romanians to that of the Nazis in Berlin, when the young student Sofia mentions that the Nazis in Berlin displayed the same behaviour. This comparison with the Nazis is perhaps not so far-fetched, because at that time the Iron Guard, the representatives of the fascist movement in Romania, had some power and they were always organising protests on the streets of Bucharest against the King, who had ordered the assassination of their leader Corneliu Codreau in November 1938 (Delatant 11).

The critic underlines that Manning emphasizes the gap between the rich and the poor. The places Harriet and Guy 
visited offered good food, an example of such display is the food of the party given by the princess Teodorescu:

Roasted turkeys with breasts ready sliced, two gammons baked with brown sugar and pineapple, crayfish, salmon coated with mayonnaise, several sorts of paté, three sorts of caviar, many aspic dishes, candied fruits, elaborate puddings, bunches of hothouse grapes, pineapples and autumn raspberries, all set on silver plates and decorated with white cattleyas. (Manning 57)

Nonetheless, the peasants coming from villages did not enjoy these pleasures. During the winter, their situation was critical, therefore they travelled to Bucharest to find help. They used to stay for hours in front of the main institutions like the palace, the law courts, or the prefectures, but they never dared to get in. Defeated by hunger and cold they would go around in groups to beg. Lacking the professionality of the beggars, they would give up easily and many of them went to Cişmigiu park to sleep under the trees. Only a few could survive the cold and the hunger:

Few of them survived long. Each morning a cart went round to collect the bodies dug from the snow. Many of these were found in bunches, frozen inseparable, so they were thrown as they were found, together, into the communal grave. (Manning 178-180)

Andronescu goes on to describe men's lack of respect for women as portrayed by Manning. Professor Inchcape mentions that when women witness a dirty joke, they pretend not to understand it, and that young women are "the most conventional jeunes filles in the world, and the most knowing. 'Sly' Miss Austen would have called them" (Manning 36). Harriet describes a conversation between a Romanian man and his German friend about women. As they walk down the street, the Romanian tells the German about the price of every woman they meet along the way. The German asks in exasperation if there are any decent women in Romania, and the Romanian replies that there are, but they are too expensive (Andronescu 27). Harriet shows her appreciation for the women who study law in Romania, because in England, a law degree is an extraordinary undertaking. To this, Inchcape responds that "here it doesn't mean anything ... They all take law degrees. That qualifies them to become second assistant stamp-lickers in the civil service" (38). It seems that Romanians can absorb information, but they lack creativity and are incapable of putting their knowledge into practice: "all Rumanians are much of a much-ness. They can absorb facts but can't do anything with them. A lot of stuffed geese, I call them. An uncreative people" (38).
The critic continues with the problematic relations between the Jewish community and the Romanians. The Jews, represented in the novel by the Druckers, a wealthy banking family, show no fear of war, but not for stupid reasons, like the Romanians, but for well-considered reasons (Andronescu 27). Mrs Hassolel assures Harriet and Guy that the Germans will not occupy Romania because "the Rumanians are clever in their way. Last war, they gained much territory. This time they will keep a foot in each camp and come out with even more" (Manning 106). The Jews believe that "if it were not for us Romania would be on her knees", and they could buy and sell the country a dozen times (107). Although the Jews work hard, save, and bring prosperity to the country, the Druckers complain that the Jews are still persecuted by the Romanians and believe that the Romanians "are content to do nothing but eat, sleep and make love. Such is their nature. The Jews and the foreigners, they run the country" (108). In the eyes of the Jews, then, the Romanians are snobbish and suffer from a sense of inferiority to the foreigners and the Jews who run the country for them because they are too lazy to do it themselves (154). The Druckers also believe that the peasants are worth nothing, they are just hopeless "beasts" and there is nothing for them to do (110).

Andronescu concludes the article by mentioning that Paris was occupied by the enemy and Guy gave a party to celebrate the success of the play "Troilus and Cressida", which he himself had directed and performed at the university. While they were celebrating, a woman entered the room angrily and admonished them for making such a noise. They were asked what they were doing there, if they had lost the war. They replied that they might have lost a battle, but they would not lose the war. In a conversation about the situation of Romania, it became clear that the country could no longer defend its great estates, i.e. Bukovina and Bessarabia, and Harriet concluded that they had better try to preserve and defend their own lives (Manning 318).

In a review entitled "O geloasă" (“A Jealous Woman") of the translation of The Balkan Trilogy into Trilogia Balcanică (1996) by Diana Stanciu, the writer and translator Grete Tartler (1996) argues that the main theme of the first volume is Harriet's jealousy of Sofia, who used to be Guy's girlfriend in Bucharest. Tartler believes that this is the reason why Harriet finds Bucharest hostile and makes disparaging descriptions about the city and its people (19). The tone with which Tartler describes the first volume is even more negative than Andronescu's. Andronecu at least limited himself to presenting events as Manning described them, even if most of these events were not pleasant for the reader, but Tartler assumes that this volume is exclusively Manning's negative view of Romania. The reviewer notes that Manning's contact with local people is artificial, as she 
only encounters gipsies, beggars, hotel staff, and the Taraful (a small band playing traditional Romanian music) who played in the restaurants she visited (19).

According to Tartler, Manning, without realizing it, implying that this was not her intention, also refers to positive aspects of Romania at the time, such as the tasty food, the description of the Athénée Palace restaurant, the drinks and sweets of Capșa, and the culinary parties of Princess Teodorescu. Tartler believes Manning is ignorant because she did not know who Armand Călinescu was, the prime minister assassinated by the fascists Iron Guard (19). Tartler concludes that the heroine of the book is "a snob and an uncultured woman" because she considers the architecture of the street Calea Victoriei "terrible" and the coachmen who drive their trăsuri (horse-drawn carriages steered by drivers in green costumes with white letter belts (Deirdre 91)) should not be introduced in the novel because they disappeared from the landscape of Bucharest several decades ago (Tartler 19). The critic concludes that Manning's ignorance can be justified by her blind jealousy (19).

In the preface to the third volume of the trilogy, Friends and Heroes into Prieteni și eroi (1996), the Romanian historian Neagu Djuvara assesses Manning's work from a point of view as caustic as Tartler's. Djuvara notes that Manning does not understand Romania, and "the description of the place and the people is dark and malevolent, in a word, a caricature" (335). The historian makes it clear that he is not a literary critic and therefore will not discuss the literary value of the work, but he does want to point out some aspects that disappointed him. First, reading the title, Djuvara believed that the trilogy would be a masterpiece like D.H. Lawrence's Alexandrian tetralogy. However, he only discovered:
A banal string of sentimental intrigues and psychological situations presented on a hideous historical background that characterizes Olivia Manning's novel, which has nothing that could resemble Lawrence Durrell's gorgeous fresco, a masterpiece of psychological analysis and sociological understanding of the Egyptian Alexandria society between the two wars. Nothing. I would even say that as a literary genre, I would classify it at the antipode of Durrell's work (335)

The historian believes that readers were drawn to Manning's talent for describing places and characters in two or three stages, and this was probably why the BBC adapted the novel as a series.

Like Tartler, Djuvara accuses Manning of lacking culture because she never travelled to Mediterranean countries like Spain, Greece, and Italy. Had she done so, she would have known that the multitude of people she met on Calea Victoriei dressed ridiculously is not typical of Romania, as such landscapes can be seen in other countries as well (335). Djuvara believes that "Manning sprinkles mud from antipathy and contempt. In Bucharest, she sees nothing but dust, dirt, and beggars" (336). He insists that beggars are her obsession because that is all she sees when she walks down the street and she tries to describe them without racial nuance (336). Djuvara mentions that among all the people she meets in Bucharest, Manning hardly meets any decent Romanians. The only Romanians she seems to appreciate are the young Jewish Sasha, his father, an economist named Klein, and the housekeeper who takes care of Sasha (336). Aside from these characters, Manning has not met a Romanian worthy of respect, and she devotes herself to criticising Sofia, her husband's alleged ex-girlfriend, for being "stupid and whiny and wearing too much makeup" (336). Djuvara concludes that if Manning had been a gifted writer, she would have been an interesting subject for psychoanalytic analysis (336).

As can be observed, both the censors and the critics made no distinction between fiction and non-fiction. This means that they consider the book as autobiography and not as a novel, because for them Olivia Manning, the author, is the same as Harriet Pringle, the character. Therefore, Harriet's descriptions of Bucharest and its inhabitants are not interpreted as fiction, but as Manning's autobiography. Both censors and critics have focused on and criticised the same aspects, such as Manning's vision of poor peasants, beggars and Jews, the former being somehow appreciated by Manning, although they all represent otherness. The existence of beggars and poor peasants cannot be denied, but Manning's attitude towards them is somewhat condescending. This could be partly due to her lack of travel culture, as Romania was the first foreign country she visited, so she might have been impressed by its otherness, and partly due to her belief that "Britain was supreme in the world, and British the most fortunate of people (qtd. in Steinberg 88). As Andrés Oliver (2018) mentions "the British group are on a mission in Romania, so they enjoy certain privileges simply for being British, and they identify the natives as Other...They are well aware of their own otherness (most of them know very little of the language and cultures of these countries)" (109).

Olivia Manning /Harriet Pringle thus distinguishes herself from the Romanians and perceives their culture and lifestyle with a critical eye (Andrés Oliver 116). She is aware of her class and observes and describes how the different social ranks should behave. For instance, "Harriet narrates how only peasants and servants walked in the road while the new bourgeoisie walked on the pavement. However, and for 
her own comfort, she decides to walk in the road too, as she is a foreigner, and she does not need to worry about these socially imposed classist rules" (Andrés Oliver 118-119). Like Mrs Drucker, Manning dehumanizes the peasants considering them less then beasts as "they had not the beauty or dignity of beasts. They treated their animals and their women with the simple brutality of savages" (Manning 133). As Andres Oliver notes, she feels hostility toward peasants, and this description reinforces the Balkanist stereotype as presented by Todorova: "they seem to be backward, primitive, lazy, misogynist, and cruel” (120).

The only Romanian character she seems to appreciate is Sasha Drucker, the Romanian Jew she and Guy protect from the Iron Guard. Even though she likes Sasha, that does not mean she feels sorry for the Druckers when they complain that they are being persecuted by Romanians. At first, she thinks the Jews are responsible for their situation and are excluding themselves from society: "Perhaps that is the trouble,' said Harriet, 'that [Jews] live apart. Your first loyalty is to your own race. And you all grow rich. The Rumanians may feel you take from the country and give nothing back"' (Manning 108). However, when she meets Sasha, she understands that "his status as an outsider is largely thrust upon him" (Steinberg 94). Thus, she makes a clear difference between "a foreigner" and "a Jew". "A foreigner" is an alien, someone who belongs to somewhere else, while "a Jew" belongs nowhere (Steinberg 94). In the traditional view, Steinberg (95) explains, the nations that excluded the Jews blamed them for segregating themselves, and when they tried to integrate, they were blamed for that as well. Therefore, they were a constant outsider. The Pringles are foreigners who can return to Britain at any time, but the Drucker family are German Jews living in Romania because they were forced to leave Germany. So, there is nowhere for them to go and their existence in Europe is precarious (Steinberg 94).

Finally, in the preface to Marea șansă, the historian Dennis Deletant (1996), an expert on Romanian history, introduces Harriet and Guy Pringle and their new life in a Bucharest threatened by war. Deletant points out that Manning renders for the English reader the Bucharest of 1939-1940 through an intelligent, lively and amusing style (1). However, the historian stresses that Romanian readers would not feel the same as the English, as they might find it "biased and resentful" (1). When the series based on the novel was issued by the BBC, Horia Georgescu, a representative figure of the Romanian community in England, denounced the series as "repulsive" and claimed that the trilogy was "a transvestite of my country and its people, on which she sheds her own venom" (qtd. in Deletant 1). Georgescu believed that Manning did not understand the Romanian people and the difficult situation Romania was in at the time, and therefore her view was wrong (1). It seems that Georgescu was particularly indignant about Manning's references to the beggars she and her husband encountered throughout Bucharest. Harriet could not get used to their presence, while "Guy, during his apprentice year, had grown accustomed, if not injured to the sight of white eyeballs and running sores, to have stumps and withered arms and the breasts of nursing mothers thrust into his face" (Manning 22).

It could be mentioned that Georgescu's response to Manning's descriptions is not entirely coherent, for even today there are beggars everywhere in Bucharest, even the mutilated ones Manning describes. However, this tendency of the Romanian elite to ignore reality is nothing new, as this article proves; critics dedicated fiercely to criticising Manning precisely because she portrayed a reality that they keep ignoring, a reality, which, unfortunately, not entirely, but bits of it can be seen even nowadays. Deletant agrees that Harriet and Guy's experiences in Romania are not significantly different from those of the British in Romania in the 1930s, nor from Deletant's own experiences in the 1960s (2). The historian (2) reminds Georgescu that he has probably not visited his country since the war, so his irritations with Manning's work are perhaps not entirely justified. Georgescu also found Harriet's reaction offensive when she reached Greece "'To feel safe!' she said. 'Simply to feel safe! It's marvellous to be among people who are on your side." (Manning 678). Harriet's reaction is completely understandable considering she is an Englishwoman and "Britain stayed against Nazi Germany and its allies, including Romania” (Deletant 2). Olivia or Harriet explains that Romania was going through difficult times and therefore one could feel safer reaching another country:

Before Guy could speak again, Mortimer Tufton, who had no patience with the conjectures of inexperienced youth, broke in with a history of Russian-Rumanian relations, proving that only Allied influences had prevented Russia from devouring the Balkans long ago. Rumania, he said, had been invaded by Russia on eight separate occasions and had suffered a number of 'friendly occupations', none of which had ever been forgotten or forgiven. 'The fact is,' he concluded, 'the friendship of Russia has been more disastrous to Rumania than the enmity of the rest of the world.' (Manning 329-330)

Deletant underlines that Manning's description of Bucharest as a city of money, food, and sex, might have been accentuated by her personal difficulties. Being only twentyfour years old, she and her husband fled from England and reached Bucharest in a tumult of social confrontations for which she was not prepared (2). Deletant states that there 
was no wonder that she became very jealous of her husband because of his premarital relationships, which he never stopped cultivating (2). Thus, these situations might have negatively influenced the image of the places and people portrayed in the trilogy (2). Deletant states that someone who knew Olivia Manning while living in Bucharest described her as a

Weak and pale girl, with a small, oval face, round, bright eyes and thin legs. It was not easy to be approached. She spent most of her time locked in the house, above the typewriter, while her husband, a gentle and friendly fellow, went for a beer with friends and taught an absurd form of Communism (qtd. in Deletant 2-3).

In an effort to justify the difficult situation Romania found herself in throughout Manning's novels, Deletant provides a detailed historical review from the Paris Peace Agreement in 1919 to the Ion Antonescu' alliance with the Iron Guard. Fearing occupation by the Soviets, Romania joined the Rome-Berlin Axis on July 4, 1940, and Carlos II asked Hitler to send a German military mission to Bucharest. But Hitler made his protection conditional on the settlement of major territorial disputes with Hungary and Bulgaria over Transylvania and Dobrogea (Deletant 6). So South Dobrogea was ceded to Bulgaria according to an agreement signed on August 21. Instead, Carlos II received Hitler's guarantees, but it was too late to keep his throne (6). After the appointment of Ion Antonescu as Prime Minister in September 1940, the king abdicated, placed his young son Mihai (Michael) on the throne, and fled Romania by train (6). Antonescu asked the leader of the Iron Guard, Horia Sima, to cooperate, but the lack of discipline of the legionaries, their violence and anti-Semitism led to disagreements between Antonescu and Sima (6). This situation also angered the Germans, as it put a stop to their attempts to further control the Romanian economy. In this context, the members of the British community were advised to leave Romania in October 1940, and Olivia Manning and her husband made their way to Athens (6).

In conclusion, this paper shows that at the time Olivia Manning lived in Romania, 1939-1940, the country was going through a severe political and economic crisis. On the one hand, the king Carol II was forced to negotiate with Hitler in order to obtain military support, negotiations that eventually led him to abdicate in 1940, leaving the throne to his young son Michael. Too inexperienced to rule alone, Michael needed the help of General Antonescu, who collaborated with Sima, the leader of the fascist movement. In the background, the fascists Iron Guard were still conducting their violent marches and inciting the peasants to join them. Since the peasants were so poor, they thought that the fascists would fight to improve their situation, and they travelled to Bucharest to protest and look for a possible solution. The poor became even poorer, but the upper class continued to be rich. This was the landscape Manning found when she reached Romania, and she reproduces this landscape in her novel. On the one hand she describes the poor situation of the peasants, the eternal presence of beggars, the strikes and violent actions of the fascists, the insecure life of the Jews, and on the other hand she depicts the opulent parties of the upper class, the tables overloaded with refined food and the extravagant life of some members of the royal family. These aspects were sharply criticised by the censors when they reviewed the novel in 1960, so much so that they decided not to authorize the translation of the book and introduced it in the Secret Library. The consequence of this decision was that literary critics, scholars, journalists and ordinary readers had no access to either the original or a translation during the communist period. It was not until 1996, seven years after the fall of the regime, that a translation of Diana Stanciu was published in Bucharest by the Univers publishing house.

The critics did not hesitate long to publish their reactions to the novel, which were not positive. Like the censors, the critics recognised and criticised the same aspects, going beyond the censors' reactions, for they even insulted Manning by calling her uncultured, untalented, and unworthy of "psychoanalytic analysis" because she was not a gifted writer. It seems that these critics read the censor's report on Manning and based their criticism on that report. Or it seems that their view of Romania was the same as that of the censors, since they highlighted and rejected the same aspects as the censors, with the difference that at the time they reviewed the novel there was no censorship board and they could even afford to insult the author. Only Deletant agreed that Manning's portrayal of Romania was not far from reality, as other Britons in 1930s Romania and Deletant himself in the 1960s experienced the same Romania Manning describes in her novels. Deletant explains that the Romania of 1939-1940 was the result of political decisions that led the country into a severe crisis that paved the way for World War II. The dismissive attitude of the censors and the harsh criticism of the critics after the communist period seem to have deterred the interest of other translators and publishers, because the novel was no longer translated, and it was only in 2016 that the 1996 edition was reissued under the title Marea şansă. Therefore, The Great Fortune did not have a great success in Romania, especially during the communist period and not too much after the regime, because when one describes, as Manning does, a reality that nobody wants to see, one usually evokes rejection. 


\section{Works Cited}

Archival Documents in Romania:

Arhivele Naţionale ale României: Comitetul pentru presă și tipărituri. Dosar 11/1964.

Arhivele Naţionale ale României: Comitetul pentru presă şi tipărituri. Dosar 10/1964.

Arhivele Naţionale ale României: Comitetul pentru presă și tipărituri. Dosar 7/1960.

Arhivele Naţionale ale României: Comitetul pentru presă şi tipărituri. Dosar 10/1949.

Arhivele Naţionale ale României: Comitetul pentru presă și tipărituri. Dosar 6/1951.

\section{Other Works Cited:}

Andronescu, Șerban. "Cărti despre România apărute în Occident înainte de 1989. Olivia Manning: The Balkan Trilogy." Steaua February 1992, pp. 26-27.

Andrés Oliver, Carmen. A Literary Reading of Olivia Manning's World War II Trilogies: War Narration, Place and End of Empire, and Gender Roles in The Balkan Trilogy and The Levant Trilogy. Diss. Autonomous University of Barcelona. Autonomous University of Barcelona, 2018.

Bloom, Harold. British Women Fiction Writers 1900-1960. Volume two. Chelsea House Publishers, 1998.

Clark, Roland. European Fascist and Local Activists: Romania's Legion of the Archangel Michael (1922-1938). Diss. University of Pittsburgh. University of Pittsburgh, 2012.

Corobca, Liliana. Instituţia cenzurii comuniste în România 19491977 vol.I. Ratio et Revelatio, 2014.

---. Controlul cărţii. Cenzura literaturii în regimul comunist din România. Cartea Românească, 2014.

Costea, Ionut, István Király and Doru Radosav. Fond Secret. Fond "S" Special. Cluj-Napoca: Dacia, 1995.

Deletant, Dennis. "Prefață.” Trilogia Balcanică. Univers, 1996, pp.1-6.

---. "Cheating the Censor: Romanian Writers under Communism." Central Europe. 2008, pp. 122-171.

Deirdre, David. Olivia Manning, a Woman at War. Oxford University Press, 2012.

Djuvara, Neagu. "Punctul de vedere al unui istoric după o lectura inconfortabilă." Trilogia Balcanică. Univers, 1996, pp. 335-38. Web.

Doinaş, Ștefan Augustin. Censorship in Romania. Ed. Vianu Lidia. Central European University Press, 1998, pp. 28-39.

Foster, Roy. Olivia Manning, a Woman at War. Ed. Deirdre David. Oxford: Oxford University Press, 2012.

Iancu, Carol. Emanciparea evreilor din România (1913-1919). Translated by Ţicu Goldstein. Editura Hasefer, 1998.

Jauss, Hans Robert. Toward an Aesthetic of Reception. Trans. Timothy Bahti. Minnesota: University of Minnesota Press, 1982.

Manning, Olivia. The Great Fortune. William Heinemann, 1960.

---. The Spoilt City. William Heinemann, 1962.

---. Friends and Heroes. William Heinemann, 1965.

---. The Balkan Trilogy. Penguin Books, 1981.

---. The Danger Tree. Weidenfeld \&Nicolson, 1977.
---. The Battle Lost and Won. Weidenfeld \&Nicolson, 1978.

---. The Sum of Things. Weidenfeld \&Nicolson, 1980.

---. The Levant Trilogy. Penguin Books, 1982.

---. The Balkan Trilogy. Penguin Random House Books, 2011.

---. Marea Șansă. Translated by Diana Stanciu. Univers, 1996.

---. Trilogia Balcanică. Translated by Diana Stanciu. Univers, 1996.

---. Prieteni şi eroi. Translated by Diana Stanciu. Univers, 1996.

---. Marea şansă. Translated by Diana Stanciu. Univers, 1996.

“Olivia Manning şi imaginea Bucureştiului”. Convorbiri literare January 1997, p. 10.

"Snob". Merriam-Webster Online Dictionary. Merriam-Webster Online, August 10, 2020, www.merriamwebster.com/dictionary/snob.

Scurtu, Ioan, Theodora Stănescu-Stanciu, Georgiana Margareta Scurtu. "Decret-lege privind introducerea stării de asediu." Istoria României între anii 1918-1940. Documente și materiale. Editura Universităţii Bucureşti, 2001, pp. 120-121.

Staiger, Janet. Interpreting Films. Princeton University Press, 1992.

Steinberg, Theodore. Twentieth-Century Epic Novels. University of Delaware Press, 2005.

Stănescu, Mircea. “Arhivele românești după 1989.” Timpul May 2005, mircea-stanescu.blogspot.com/2007/12/arhivele-romnetidup-1989.html.

Tartler, Grete. 1996. "O geloasă.” România literară. July 28, p. 19.

Tismaneanu, Vladimir. Raport final. Comisia prezidenţială pentru analiza dictaturii comuniste din România. 2006, https://www.wilsoncenter.org/sites/default/files/media/documen ts/article/RAPORT\%20FINAL_\%20CADCR.pdf

Todorova, Maria. Imagining the Balkans. Oxford University Press, 1997. Print.

Zimbroianu, Cristina. "Evelyn Waugh's Decline and Fall and Vile Bodies in Franco's Spain and Communist Romania." Philologica Canariensia no. 25, 2019, pp. 86-106, https://doi.org/10.20420/PhilCan.2019.259 